\title{
The Role of Self-Efficacy and Entrepreneurial Self-Efficacy on the Entrepreneurial Intentions of Graduate Students: A Study among Omani Graduates
}

\author{
Pappusamy Udayanan
}

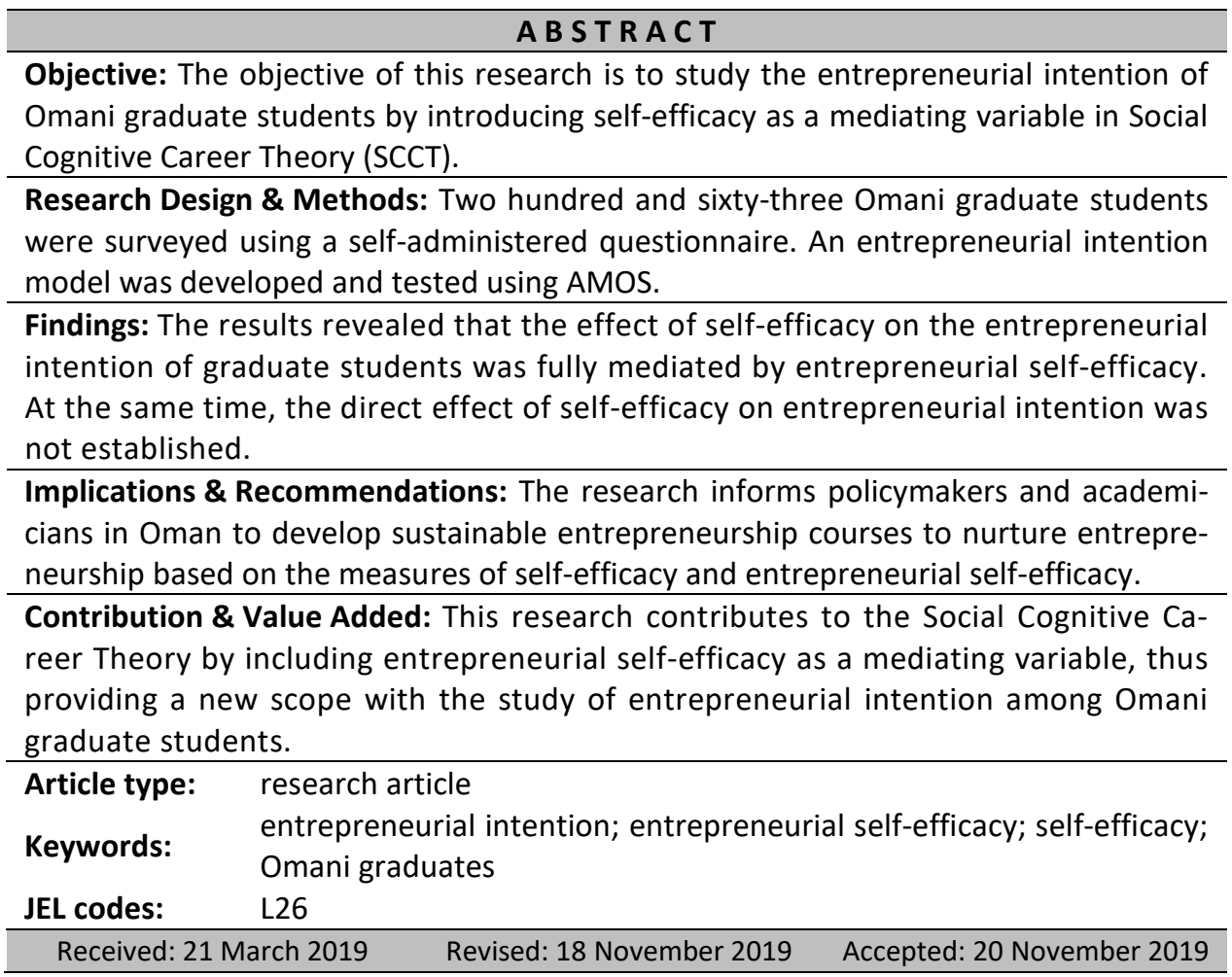

\section{Suggested citation:}

Udayanan, P. (2019). The Role of Self-Efficacy and Entrepreneurial Self-Efficacy on the Entrepreneurial Intentions of Graduate Students: A Study among Omani Graduates. Entrepreneurial Business and Economics Review, 7(4), 7-20. https://doi.org/10.15678/EBER.2019.070401 


\section{INTRODUCTION}

Entrepreneurship helps in the socio-economic development of countries (BarNir, Watson, \& Hutchins, 2011; Hafer, 2013; Thurik \& Wennekers, 2004), and entrepreneurial attitude stimulates the GDP of a country (Doran, McCarthy, \& Marie O'Connor, 2018). Entrepreneurship is a viable alternative for employment generation (Van Gelderen, Brand, van Praag, Bodewes, Poutsma, \& Van Gils, 2008) while neglecting entrepreneurship as a strategic component for growth from a five-year development plan of a country would eventually lead to unemployment issues (Kayed \& Kabir, 2011). Developing young graduates as entrepreneurs augments employment measures adopted by a country through the creation of self-employment opportunities. Students from developing economies are more likely to pursue entrepreneurship as their career in comparison to students from developed economies (Plewa \& Struwig, 2011). However, motivating graduate students to pursue entrepreneurship as their career is the most challenging task for both governments and universities. Many studies have identified self-efficacy as a major determinant of entrepreneurship and entrepreneurial intention. Self-efficacy means one's own belief to complete tasks successfully. General self-efficacy is useful when an individual faces challenging situations, and when one wants to establish a firm (Locke \& Baum, 2007). Practitioners and academicians coordinate efforts to develop entrepreneurial culture by focusing on graduate entrepreneurship and entrepreneurial intention (Krueger, Reilly, \& Carsrud, 2000; Nabi \& Holden, 2008). Strong entrepreneurial intention (EI) is likely to eventually result in attempts to start a new venture. The Social Cognitive Career Theory is a widely accepted framework to study entrepreneurial intention (EI), which is a underresearched in the Gulf region.

The objective of this research is to study Omani graduates' entrepreneurial intention by introducing entrepreneurial self-efficacy as a mediating variable in the Social Cognitive Career Theory (SCCT) framework developed by Lent, Brown, and Hackett (2002). The study was conducted by surveying 263 graduate students with a self-reporting instrument. The article follows in four major sections. The first section focuses on the review of literature with hypotheses and model development. The second section discusses the materials and methods used in this study. The third section focuses on the model testing, and the fourth section discusses the results, followed by a conclusion and future research directions.

\section{LITERATURE REVIEW}

This research focuses on individual cognition related factors of the Social Cognitive Career Theory (SCCT), that is, the self-efficacy, outcome expectations, and personal goals based on the work of Lent, Brown, and Hackett (2002). The SCCT framework focuses on career interests and their relation to career choices. Self-efficacy (SE), outcome expectations, and personal goals control one's own career (Lent, Brown, \& Hackett, 2000). "Self-efficacy is one's own beliefs on the capabilities to complete a task successfully" (Boyd \& Vozikis, 1994). SCCT asserts that SE influences personal goals, which determines the individual's action based on the expected outcomes. Outcome expectation is the "belief about the consequences of performing a behaviour" (Lent et al., 2002, p.262). The level of SE influences the outcome ex- 
pectations and their success and failures; people are discouraged by failures when they experience easy success. However, effort and perseverance can overcome obstacles and lead to a stable sense of SE (Wood \& Bandura, 1989). Perseverance means achieving goals in challenging times. Thus, an individual with high SE will persevere in challenging times (Bandura, 2002). Self-efficacy and outcome expectations influence the career choice, goals, and ambitions. Hence, a goal is the conviction to perform an activity that affects an outcome (Bandura, 1986, quoted in Boyd \& Vozikis, 1994). That is, individuals with a high level of SE and the wish to achieve their expected outcomes will help them in achieving their goals. Lent, Brown, and Hackett (1994) claim that one's choice of career depends on the person's SE and outcome expectations. Therefore, I propose the following hypotheses:

H1: Self-efficacy positively influences one's outcome expectations.

H2: Self-efficacy positively influences one's conviction to perform an activity.

Achieving desired goals creates a positive change, and it positively influences entrepreneurial commitment (Jansen, 2004), entrepreneurial intention (do Paço, Ferreira, Raposo, Rodrigues, \& Dinis, 2011), the need for achievement, and persistence (Wu, Matthews, \& Dagher, 2007). Wu and Li (2011) focus on different constructs - namely perceived benefits and sacrifices - to study entrepreneurial intention, which is synonymous with expected outcomes. They find that the perceived benefits of entrepreneurship explain the formation of entrepreneurial intention. Outcome expectations and entrepreneurial intention vary according to an individual's psychological and socio-economic conditions. What further determines entrepreneurial intention is financial security (Van Gelderen et al., 2008), the need for achievement (Dinis, do Paco, Ferreira, Raposo, \& Gouveia Rodrigues, 2013), and perceived sacrifices (Wu \& Li, 2011).

Various research perspectives argue that SCCT is a valid framework to study the relationship between SE and entrepreneurial intention (Austin \& Nauta, 2016; Liguori, Bendickson, \& McDowell, 2018). Intentions influence the choice of actions and predict future behaviours. Many researches on entrepreneurial intention use Ajzen's (1991) and Ajzen's and Fishbein's (2000) theory of planned behaviour (Aloulou, 2015; Krueger at al., 2000; Van Gelderen et al., 2008; Zhang, Wang, \& Owen, 2014). Another group reveals a relationship between SE and entrepreneurial intention (Bayrón, 2013; Bar Nir et al., 2011; Kristiansen \& Indarti, 2004; Segal, Borgia, \& Schoenfeld, 2002). I derive the following hypotheses from extant literature:

H3: One's perception of consequences for performing a behaviour influences the conviction to perform an activity.

H4: Self-efficacy positively influences entrepreneurial intention.

H5: One's conviction to perform an activity influences entrepreneurial intention.

\section{The Mediating Role of Entrepreneurial Self-Efficacy}

SE influences a person's behaviour to start a business and the level of "task persistence" in challenging times (Bandura, 1986, quoted in Boyd \& Vozikis, 1994). Individuals with higher SE in their early stages of career will possess high entrepreneurial intentions and will be involved in entrepreneurial tasks (Boyd \& Vozikis, 1994). SE can be general or domain-specific. General SE is an individual's ability to perform a broad range of tasks (Luszczynska, Scholz, \& Schwarzer, 2005), whereas domain-specific SE is 
a person's ability to effectively perform various entrepreneurial tasks (Chen, Greene, \& Crick, 1998). Research proves that SE influences a person's career choice (Lent et al., 1994) and determines entrepreneurial intentions and behaviour (Fietze \& Boyd, 2017; Laguna, 2013; Naktiyok, Karabey, \& Gulluce, 2010; Newman, Obschonka, Schwarz, Cohen, \& Nielsen, 2019; Pihie \& Bagheri 2013; Ren, Ping, \& Li, 2018; Sequeira, Mueller, \& Mcgee, 2007; Sušanj, Jackopec, \& Miljković, 2015; Wilson, Kickul, \& Marlino, 2007; Zhao, Seibert, \& Hills, 2005). While many researchers find direct influence of entrepreneurial self-efficacy (ESE) on entrepreneurial intentions (EI) the role of ESE as a mediating variable between SE and EI of graduate students is less researched in Oman. McGee et al. (2009) assert that scholarship should include ESE in the EI model. ESE is one's ability to start and successfully manage a venture with required entrepreneurial skills in marketing, human resources, and finance (Chen et al., 1998). Hence, I propose the following hypotheses:

H6: Entrepreneurial self-efficacy positively influences entrepreneurial intention.

H7: Entrepreneurial self-efficacy mediates the relationship between self-efficacy and entrepreneurial intention.

\section{MATERIAL AND METHODS}

This study is descriptive and quantitative in nature. The sample included graduate students enrolled in a business program at a private college in Muscat. A non-probability method of sampling was used. Using judgemental sampling, three hundred questionnaires were distributed to the final year undergraduate students, out of which 274 students responded. Among the received responses, 263 responses were usable. The final sample constituted 137 male and 126 female students. The data was collected through self-administered questionnaire. The questionnaire consisted of eight items measuring general SE adapted from Chen, Gully, and Eden (2001), and six statements measuring entrepreneurial intention adapted from Liñán and Chen (2009). One global statement measured ESE and entrepreneurial goals, and four independent items measured outcome expectations were adapted from Segal et al.(2002). Outcome expectations were measured by assessing respondents' perception of the ability of self-employment in "making money," "providing financial security," "achieving independence," and "satisfying the need for achievement." The questionnaire was pilot tested on 25 students for reliability. Based on the measure of reliability, the eight-items scale measuring general SE was reduced to six items and the six-items scale measuring entrepreneurial intention was reduced to three items. The final reliability measures of the 15 -item scale (excluding demographic variables) was 0.958 . Table 1 details the reliability measures. Data was analysed with AMOS 23 and SPSS.

Table 1. Reliability measures

\begin{tabular}{|c|c|c|c|c|c|}
\hline Mean & Minimum & Maximum & Variance & N of Items & Cronbach's Alpha \\
\hline 3.712 & 2.970 & 4.916 & 0.244 & 15 & 0.958 \\
\hline
\end{tabular}

Source: own calculation in SPSS. 


\section{RESULTS AND DISCUSSION}

The hypotheses were tested by applying multiple regression in SPSS. The aggregated scores of general SE items and El items were used to run the regression.

Outcome expectations were assessed based on four individual measures that focused on earning money, financial security, independence, and the achievement of needs. The following statements were used to measure outcome expectations: "What do you think is the probability of making money by being self-employed?"; "What do you think is the probability of having financial security by being self-employed?"; "What do you think is the probability of being independent if you are self-employed?"; "What do you think is the probability of satisfying your need for achievement if you are self-employed?" Aggregated scores of SE statements were considered when running the regression path. Table 2 shows the standardised regression weights with R-Squared measures for OE and GSE.

Table 2. Standardised regression weights

\begin{tabular}{|c|c|c|c|c|c|c|}
\hline \multicolumn{3}{|c|}{ Variables with path } & Estimate & S.E. & C.R. & p \\
\hline Making Money (MM) & $<---$ & \multirow{4}{*}{$\begin{array}{c}\text { General } \\
\text { Self- Effi- } \\
\text { cacy } \\
\text { (GSE) }\end{array}$} & 0.908 & 0.041 & 35.127 & $* * *$ \\
\hline Financial security (FS) & $<--$ & & 0.713 & 0.058 & 16.473 & $* * *$ \\
\hline Independence (IND) & $<--$ & & 0.639 & 0.016 & 13.431 & $* * *$ \\
\hline Need for Achievement (NACH) & $<--$ & & 0.947 & 0.028 & 47.913 & $* * *$ \\
\hline
\end{tabular}

Significant codes: $* * * 0.001$. R-squared $=0.72$.

Source: own calculation in SPSS.

Referring to the statistics in Table 2, we may infer that general self-efficacy (GSE) influences the outcome expectation variables (MM, FS, IND, NACH) with a good R-squared value of more than $70 \%$, except for the variable independence, which is less than $70 \%$.

Entrepreneurship goal was measured through a global statement that elicited response from students by asking "How likely are you to become an entrepreneur?" Table 3 shows standardised regression weights with R- Squared measure for EG and GSE.

Table 3. Standardised regression weights

\begin{tabular}{|c|c|c|c|c|c|c|}
\hline \multicolumn{2}{|c|}{ Variables with path } & Estimate & S.E. & C.R. & p \\
\hline $\begin{array}{c}\text { Entrepreneurship } \\
\text { Goals (EG) }\end{array}$ & $<---$ & $\begin{array}{c}\text { General Self-Effi- } \\
\text { cacy (GSE) }\end{array}$ & 0.99 & 0.044 & 33.248 & $* * *$ \\
\hline
\end{tabular}

Significant codes: $* * * 0.001$. R-squared $=0.72$.

Source: own calculation in SPSS.

Referring to the statistics in Table 3, we may infer that GSE determines student entrepreneurship goals with $72 \%$ of explained variance.

Table 4 shows the standardised regression weights with R-squared measures for $\mathrm{OE}$ and $\mathrm{EG}$.

The statistics from Table 4 reveal that all four variables account for $86 \%$ of the total explained variance. Two variables, namely "financial security" and "independence" have a negative influence on entrepreneurship goals. Hence the above two variables fail to positively influence entrepreneurship goals. 
Table 4. Standardised regression weights

\begin{tabular}{|c|c|c|c|c|c|c|}
\hline \multicolumn{2}{|c|}{ Variables with path } & Estimate & S.E. & C.R. & p \\
\hline \multirow{3}{*}{$\begin{array}{c}\text { Entrepre- } \\
\text { neurship }\end{array}$} & $<---$ & Making Money (MM) & 0.835 & 0.020 & 36.431 & $* * *$ \\
\cline { 2 - 7 } & $<---$ & Financial security (FS) & -0.082 & 0.024 & -3.558 & ns \\
\cline { 2 - 7 } \\
Goals (EG) & $<---$ & Independence (IND) & -0.067 & 0.097 & -2.904 & ns \\
\cline { 2 - 7 } & $<---$ & Need for Achievement (NACH) & 0.393 & 0.022 & 17.141 & $* * *$ \\
\hline
\end{tabular}

Significant codes: $* * * 0.001 ; * 0.05$ 'ns' not significant. R-squared $=0.862$.

Source: own calculation in SPSS.

El was measured by eliciting responses from the students through such statements as, "I am ready to do anything to be an entrepreneur," "I will make every effort to start and run my own firm," "I think seriously of starting a firm." The aggregated scores of the three items were used as a single measure. Table 5 shows the standardised regression weights with R-squared measure for El and GSE.

Table 5. Standardised regression weights

\begin{tabular}{|c|c|c|c|c|c|c|}
\hline \multicolumn{2}{|c|}{ Variables with path } & Estimate & S.E. & C.R. & p \\
\hline $\begin{array}{c}\text { Entrepreneurial } \\
\text { intention (EI) }\end{array}$ & $<---$ & $\begin{array}{c}\text { General Self- } \\
\text { Efficacy (GSE) }\end{array}$ & 0.895 & 0.037 & 32.445 & $* * *$ \\
\hline
\end{tabular}

Significant codes: $* * * 0.001$. R-squared $=0.80$.

Source: own calculation in SPSS.

The statistics from Table 5 reveal that SE influences El of the students. GSE explains entrepreneurial intention of the students to the extent of $80 \%$.

Table 6 shows the standardised regression weights with the R-Squared measure for El and EG.

Table 6. Standardised regression weights

\begin{tabular}{|c|c|c|c|c|c|c|}
\hline \multicolumn{2}{|c|}{ Variables with path } & Estimate & S.E. & C.R. & p \\
\hline $\begin{array}{c}\text { Entrepreneurial } \\
\text { intention (EI) }\end{array}$ & $<---$ & $\begin{array}{c}\text { Entrepreneur- } \\
\text { ship Goals (EG) }\end{array}$ & 0.933 & 0.019 & 41.843 & $* * *$ \\
\hline
\end{tabular}

Significant codes: $* * * 0.001$. R-squared $=0.87$.

Source: own calculation in SPSS.

The statistics from Table 6 reveal that the students' entrepreneurship goals positively influence their El. The goals explain their El to an extent of $87 \%$.

The students' ESE was measured by eliciting response from them about the global statement, "How confident are you that you have all the necessary knowledge, skills, and abilities to perform the tasks and activities necessary to become an entrepreneur?" Table 7 shows the standardised regression weights with the R- Squared measure for EI and ESE.

The statistics from Table 7 reveal that the students' ESE positively influences the entrepreneurial intention of the students with an explained variance of $81 \%$.

To test the hypothesis $7(\mathrm{H} 7)$, the study measured the direct and indirect effect of SE on El with bootstrapping. Path analysis with bootstrapping was performed with the variables of 
$\mathrm{SE}, \mathrm{El}$, and ESE. The Tables 8 and 9 show standardised regression weights with the R-squared measure, along with the direct and indirect effect of SE on EI of the graduate students.

Table 7. Standardised regression weights

\begin{tabular}{|c|c|c|c|c|c|c|}
\hline \multicolumn{3}{|c|}{ Variables with path } & Estimate & S.E. & C.R. & $p$ \\
\hline $\begin{array}{l}\text { Entrepreneurial } \\
\text { intention (EI) }\end{array}$ & $<--$ & $\begin{array}{c}\text { Entrepreneurial } \\
\text { Self-Efficacy (ESE) }\end{array}$ & 0.901 & 0.021 & 33.588 & $* * *$ \\
\hline
\end{tabular}

Significant codes: $* * * 0.001$. R-squared $=0.87$.

Source: own calculation in SPSS.

Table 8. Standardised regression weights

\begin{tabular}{|c|c|c|c|c|c|c|}
\hline \multicolumn{3}{|c|}{ Variables with path } & Estimate & S.E. & C.R. & p \\
\hline $\begin{array}{c}\text { Entrepreneurial } \\
\text { Self-Efficacy (ESE) }\end{array}$ & $<--$ & $\begin{array}{c}\text { General Self- Effi- } \\
\text { cacy (GS) }\end{array}$ & 0.889 & 0.050 & 31.479 & $* * *$ \\
\hline \multirow{2}{*}{$\begin{array}{l}\text { Entrepreneurial } \\
\text { intention (EI) }\end{array}$} & $<--$ & $\begin{array}{c}\text { Entrepreneurial } \\
\text { Self-Efficacy (ESE) }\end{array}$ & 0.502 & 0.040 & 9.716 & $* * *$ \\
\hline & $<--$ & $\begin{array}{c}\text { General Self- Effi- } \\
\operatorname{cacy~(GS)~}\end{array}$ & 0.448 & 0.070 & 8.663 & $* * *$ \\
\hline
\end{tabular}

Significant codes: $* * * 0.001$. ESE R-squared = 0.79; El R-squared =0.79.

Source: own calculation in SPSS.

Table 9. Direct and indirect effects

\begin{tabular}{|c|c|c|c|}
\hline Hypothesis & Direct effect & Indirect effect & Result \\
\hline $\mathrm{GS} \rightarrow \mathrm{ESE} \rightarrow \mathrm{EI}$ & $0.607 *(\mathrm{GS} \rightarrow \mathrm{EI})$ & $0.605 *(\mathrm{GS} \rightarrow \mathrm{ESE} \rightarrow \mathrm{EI})$ & Partial mediation \\
\hline
\end{tabular}

Significant code: $* 0.05$.

Source: own calculation in SPSS.

The result reveals that SE has a significant direct effect on $\mathrm{EI}$ and significant indirect effect on El through ESE.

Based on empirical studies (Table 2 - Table 9) we conclude that hypotheses ( $\mathrm{H} 1-\mathrm{H} 7)$ are confirmed.

\section{Model Development}

A model was developed with all the variables (hypotheses) and tested for its path relationship in a single run. Figure 1 shows the model with the path co-efficient.

Figure 1 reveals that the outcome expectation measures "financial security" and "independence" did not significantly influence EG of the students. However, the outcome expectation "probability of making money" significantly influenced the EG of the students. We may also observe that the effect of individual SE on EG and EI was significantly reduced. The prominent change may be observed in the mediating effects of ESE, in which partial mediation changed to full mediation. Full mediation implies that the role of SE in determining El of the students is significant when it is mediated through ESE of the students. The direct relationship between the individual SE and EI is insignificant. Table 10 shows the mediating effect achieved in the model.

Based on the results of the model (Figure 1), a revised model was developed (see Figure 2). The revised model eliminated 1 ) the financial security and independence path on 
entrepreneurship goals; 2 ) the path established between self-efficacy and entrepreneurial in-tention; and 3) the path established between self-efficacy and entrepreneurship goals. Figure 2 shows the revised path model with the standardised regression weights.

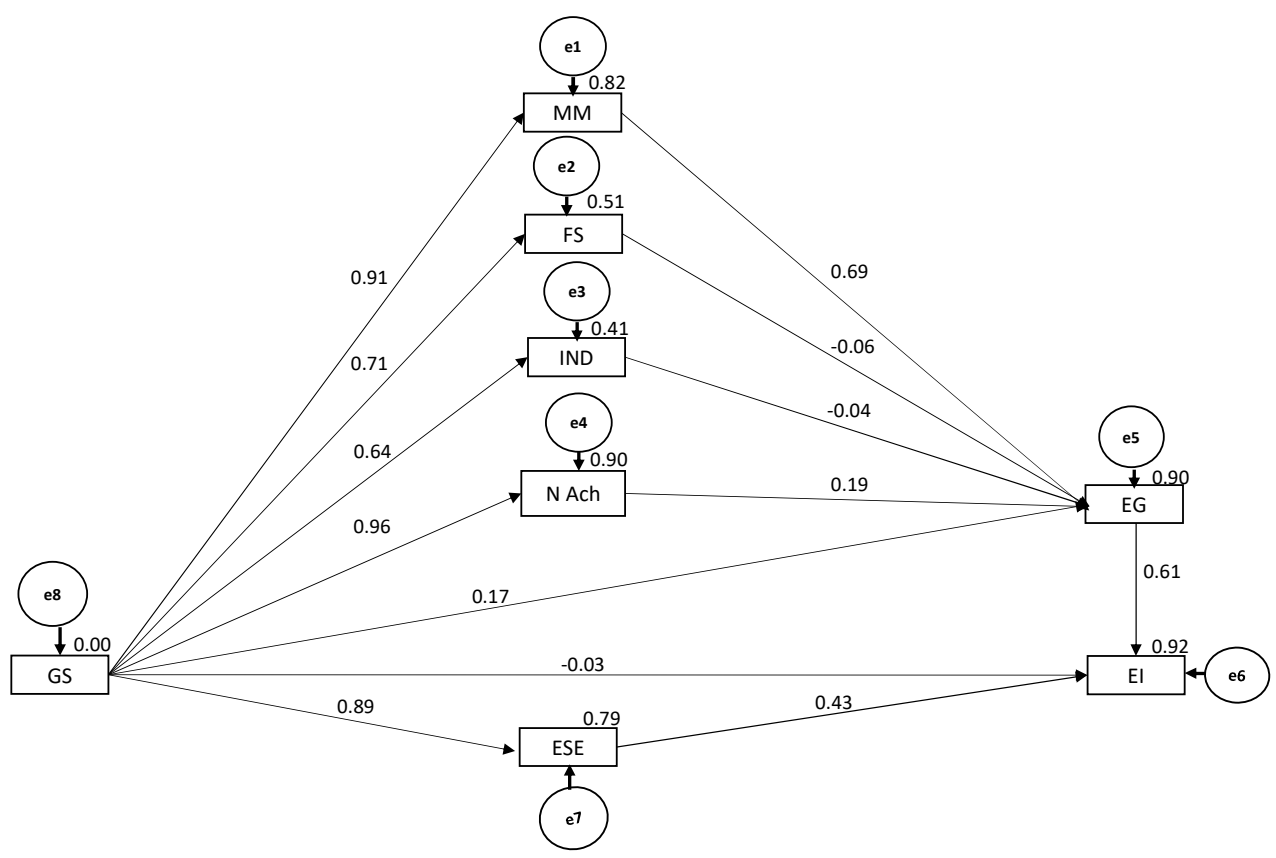

Figure 1. Path diagram of the model with standardised regression weights Source: own calculation in AMOS.

Table 10. Direct and Indirect effects

\begin{tabular}{|c|c|c|c|}
\hline Hypothesis & Direct effect & Indirect effect & Result \\
\hline $\mathrm{GS} \rightarrow \mathrm{ESE} \rightarrow \mathrm{EI}$ & $\begin{array}{c}0.889 * * * \\
(\mathrm{GS} \rightarrow \mathrm{EI})\end{array}$ & $\begin{array}{c}0.934^{* * *} \\
(\mathrm{GS} \rightarrow \mathrm{ESE} \rightarrow \mathrm{EI})\end{array}$ & Full mediation \\
\hline
\end{tabular}

Significant code: $* * * 0.001$.

Source: own calculation in SPSS.

The revised path model shows a good R-squared measure and significant path-coefficient. An improvisation of the revised path model was attempted by changing the path relationship, but a valid model could not be developed. Hence, the revised model (Figure 2 ) is the final outcome of this research.

This research studied the entrepreneurial intention of graduate students in Oman by focusing on the roles of SE and ESE in the SCCT framework. The results of the revised model (see Figure 2) differ from the work of Lent at al. (2002). When SE was tested independently (excluding other variables) for its relationship with El, the results established a positive relationship, which is similar to the findings in other research studies (Laguna, 2013; Pihie \& Bagheri, 2013; Sušan et al., 2015; Wilson et al., 2007; Zhao et al., 2005). The students with high SE showed higher interest in achieving EG, which implies their motivation to start own business. The research established a positive relationship between the students' SE 


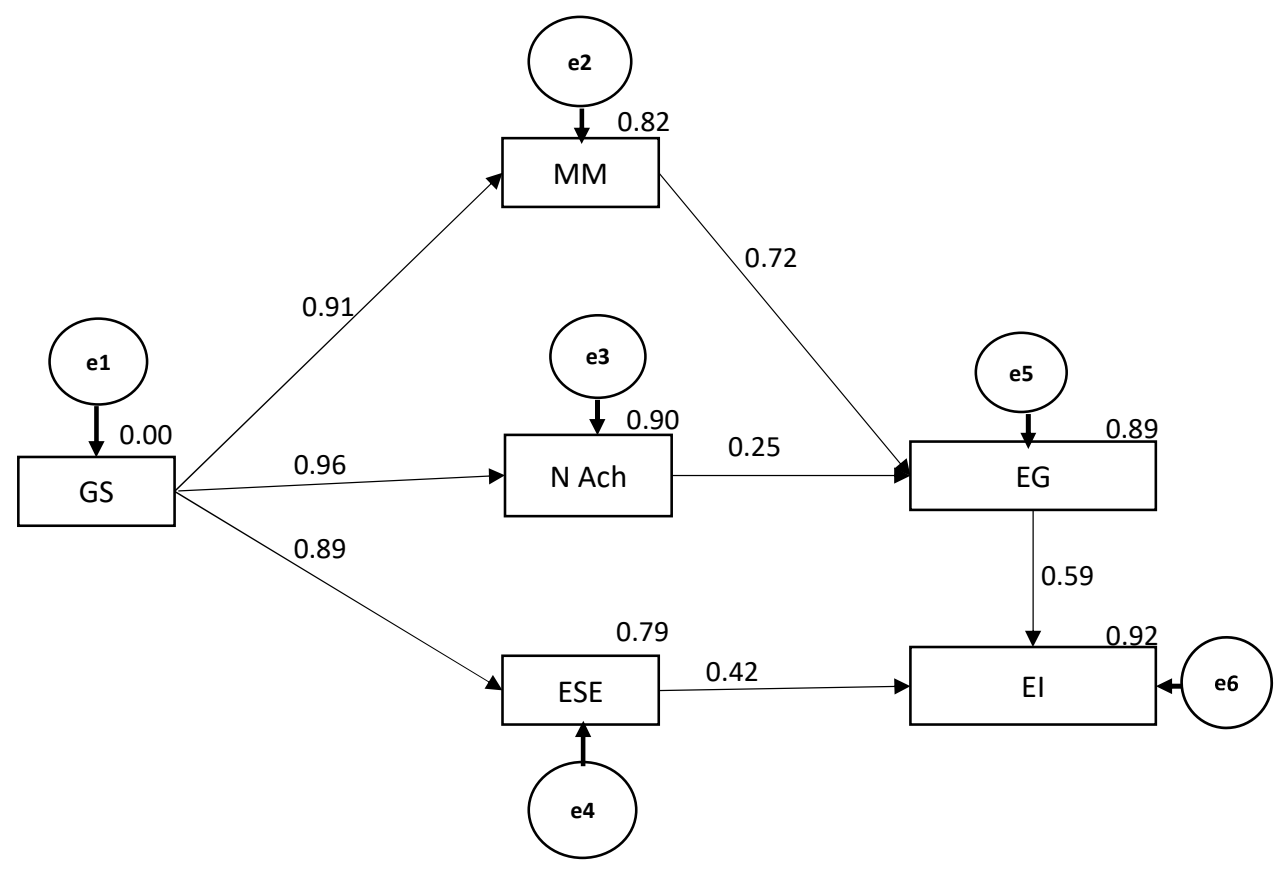

Figure 2. The revised path diagram of the model Source: own calculation in AMOS.

and all the variables of outcome expectations. The above finding confirms the role of SE in determining the outcome expectations of the students. Interestingly, not all variables of outcome expectations determined the students' EG. The study revealed that students who expected to make more money through their own ventures had stronger EG, which in turn positively determined the El of the students. The students prefer to be financially secured by being employed in a firm, thus being risk-aversive.

Omani students do not choose entrepreneurship as their career due to the fear of failure (Belwal, Al Balushi, \& Belwal, 2015). Both the government of Oman and Omani educational institutions should play a significant role in nurturing graduate students' attitude in assuming entrepreneurial risks. This can be done at universities and colleges by emphasizing entrepreneurship courses through building an entrepreneurship curriculum based on the industry-academic partnership to nurture students' business acumen. Oman lacks systematic policies that govern the relationship between colleges and industries (Issa, 2016). Hence there is an imperative to develop strategic policies that develop entrepreneurship education. The study's results are similar to the findings of Chen et al. (1998) that graduate students' entrepreneurial SE determines their EI. Graduate students' SE influences their EI both directly and indirectly through their ESE. A significant partial mediation was obtained. However, the above discussion becomes worthwhile when each of the above hypotheses is treated independently, excluding other variables. When all the hypotheses were considered in a single run (Figure 1), the outcomes varied. The explanatory power of SE for EI and EG was not significant, which implies that SE predicts El better when it is treated alone as the choice of determinant. SE failed to establish relationship with EI in a multivariate ap- 
proach. However, the role of SE in determining El can be ruled out completely, as it has a considerable indirect explanatory power. Given the above scenario, a revised model was developed (Figure 2) with ESE as the mediating variable. We should mention that many studies establish a direct relationship between ESE and El (Bar Nir et al., 2011; Krueger et al., 2000; Pihie \& Badheri, 2013; Wilson et al., 2007; Zhao et al., 2005), but do not establish a mediating relationship. This study differs from other studies, as it claims that SE explains $\mathrm{El}$ in the presence of ESE. Besides ESE, El are determined by the graduate students' EG, which in turn influenced the outcome expectation variables such as "making money" and "need achievement." Noteworthy, the "need achievement" had less explanatory power in the first model (Figure 1) but gained in the revised model (Figure 2).

\section{CONCLUSIONS}

Based on the results, we suggest that universities and colleges should focus on developing Omani graduate students' mastery experience as recommended by Wood and Bandura (1989). Overall, the current article established the roles of SE and ESE in determining El. The results of the study suggest ESE as a critical mediating factor that determines El of undergraduate students. ESE also mediates the influence of belief and motivation on El. (Odoardi, Galletta, Battistelli, \& Cangialosi, 2019). Educational institutions in Oman should develop courses that nurture ESE of the students. Entrepreneurship clubs will stimulate entrepreneurial learning (Pittaway, Rodriguez-Falcon, Aiyegbayo, \& King2011), which helps developing students' SE. Exploring the exact requirements of an entrepreneurship course that develops the ESE of graduate students is beyond the scope of this study. However, we may recommend that institutions reinforce Omani students' confidence by training them in technical aspects, such as market research, product development, and commercialisation, which will help to increase their ESE. Moreover, the ESE of graduate students can be developed by training them with the transferrable skills in areas related to business, such as marketing, finance, procurement, and human resources management, which will develop domain-specific skills.

The role of the Ministry of Higher Education is also imperative in developing the SE and ESE of graduate students by building effective educational policies. Hence, nurturing ESE will lead to the development of entrepreneurship, which is much required in Oman, as the economy faces trying times due to the decline in the economic contribution from the hydrocarbon sector. The Ministry of Higher Education in Oman has mandated all the colleges to include entrepreneurship as a course in undergraduate programs, but this course is dealt as one of the subjects for graduation. In such circumstances, this research informs practitioners and researchers about the need to nourish domain-specific ESE skills to develop holistic academic programs, which can inculcate the spirit of entrepreneurialism and nurture El among graduate students. After all, the government has a substantial role in nurturing the relationship between entrepreneurship and economic growth (Saberi \& Hamdan, 2019). Oman's government has invested in promoting Small and Medium Enterprises as the country's economic engine, as this would facilitate diversification, promote entrepreneurship, and increase employment opportunities. Government's initiatives can be supported by academicians imparting the skills through practical learning rather than focusing on theoretical courses, as asserted by Piperopoulos and Dimov (2015). 
The associative relationship between SE and ESE in determining the El should help educational policymakers, entrepreneurship educators, and universities to develop and implement multiple pedagogies so as to impart SE and ESE among graduate students.

The limitation of the study is the use of self-reported questionnaire to assess SE and ESE of students. As multiple studies suggest, ESE is a multi-dimensional construct, although there is no agreement among the researchers on the measurement construct, while ESE measuring instrument has ample room for refinement. There is also room to broaden the scope of samples by including undergraduate students from across the country. However, these limitations do not influence the study's outcome quality. As a future research direction, in light of the developed alternative model, using cognitive individual related factors of the SCCT, including ESE as a mediating variable, and incorporating the role of situational factors like environment, education, infrastructural support, resource capabilities, and socio-cultural factors, will definitely contribute to the existing body of knowledge in entrepreneurship research. Moreover, the role of psychological constructs should be thoroughly investigated for their greater understanding. Lastly, in the future, an expanded model of the above measures should be developed to empirically test and validate a comprehensive framework and research graduate student's El; thus developing appropriate intervention strategies for both academic and practical purposes.

\section{REFERENCES}

Ajzen, I. (1991). The theory of planned behavior. Organizational Behavior and Human Decision Processes, 50(2), 179-211.

Ajzen, I., \& Fishbein, M. (2000). Attitudes and the attitude-behavior relation: Reasoned and automatic processes. European Review of Social Psychology, 11(1), 1-33.

Aloulou, W.J. (2015). Entrepreneurial intention among freshmen students-application of the theory of planned behaviour in Saudi context. Journal of Enterprising Culture, 23(04), 473-500. https://doi.org/10.1108/ JSBED-02-2016-0028

Austin, M.J., \& Nauta, M.M. (2016). Entrepreneurial role-model exposure, self-efficacy, and women's entrepreneurial intentions. Journal of Career Development, 43(3), 260-272.

Bandura, A. (2002). Social cognitive theory in cultural context. Applied Psychology, 51(2), 269-290.

Bandura, A. (2012). On the functional properties of perceived self-efficacy revisited. Journal of Management, 38(1), 9-44. https://doi.org/10.1177/0149206311410606

BarNir, A., Watson, W.E., \& Hutchins, H.M. (2011). Mediation and moderated mediation in the relationship among role models, self-efficacy, entrepreneurial career intention, and gender. Journal of Applied Social Psychology, 41(2), 270-297. https://doi.org/10.1111/j.1559-1816.2010.00713.x

Bayrón, C.E. (2013). Social cognitive theory, entrepreneurial self-efficacy and entrepreneurial intentions: Tools to maximize the effectiveness of formal entrepreneurship education and address the decline in entrepreneurial activity. Griot, 6(1), 66-77.

Belwal, R., Al Balushi, H., \& Belwal, S. (2015). Students' perception of entrepreneurship and enterprise education in Oman. Education+ Training, 57(8/9), 924-947.

Boyd, N.G., \& Vozikis, G.S. (1994). The influence of self-efficacy on the development of entrepreneurial intentions and actions. Entrepreneurship Theory and Practice, 18(4), 63-77.

Chen, C.C., Greene, P.G., \& Crick, A. (1998). Does entrepreneurial self-efficacy distinguish entrepreneurs from managers?. Journal of Business Venturing, 13(4), 295-316. https://doi.org/ 10.1016/S0883-9026(97)00029 
Chen, G., Gully, S.M., \& Eden, D. (2001). Validation of a new general self-efficacy scale. Organizational Research Methods, 4(1), 62-83. https://doi.org/ 10.1177/109442810141004

Davey, T., Plewa, C., \& Struwig, M. (2011). Entrepreneurship perceptions and career intentions of international students. Education+ Training, 53(5), 335-352.

Dinis, A., do Paco, A., Ferreira, J., Raposo, M., \& Gouveia Rodrigues, R. (2013). Psychological characteristics and entrepreneurial intentions among secondary students. Education+ Training, 55(8/9), 763-780.

do Paço, A.M.F., Ferreira, J.M., Raposo, M., Rodrigues, R.G., \& Dinis, A. (2011). Behaviours and entrepreneurial intention: Empirical findings about secondary students. Journal of International Entrepreneurship, 9(1), 20-38.

Doran, J., McCarthy, N., \& Marie O'Connor. (2018). The role of entrepreneurship in stimulating economic growth in developed and developing countries. Cogent Economics \& Finance, 6(1). https://dx.doi.org/10.1080/23322039.2018.1442093

Fietze, S., \& Boyd, B. (2017). Entrepreneurial intention of Danish students: a correspondence analysis. International Journal of Entrepreneurial Behavior \& Research, 23(4), 656-672. https://doi.org/10.1108/IJEBR-08-2016-0241

Hafer, R.W. (2013). Entrepreneurship and state economic growth. Journal of Entrepreneurship and Public Policy, 2(1), 67-79.

Issa, J.H. (2016).The Impediments Facing Community Engagement in Omani Educational Tertiary Institutions. International Education Studies, 9(9), 133-145.

Jansen, K.J. (2004). From persistence to pursuit: A longitudinal examination of momentum during the early stages of strategic change. Organization Science, 15(3), 276-294.

Kristiansen, S., \& Indarti, N. (2004). Entrepreneurial intention among Indonesian and Norwegian students. Journal of Enterprising Culture, 12(01), 55-78.

Krueger Jr, N.F., Reilly, M.D., \& Carsrud, A.L. (2000). Competing models of entrepreneurial intentions. Journal of Business Venturing, 15(5-6), 411-432.

Laguna, M. (2013). Self-efficacy, self-esteem, and entrepreneurship among the unemployed. Journal of Applied Social Psychology, 43(2), 253-262.

Locke, E.A., \& Baum, J.R. (2007). Entrepreneurial motivation. In J.R. Baum, M. Frese, \& R. Baron (Eds.), The psychology of entrepreneurship (pp. 93-112). Mahwah, NJ: Lawrence Erlbaum.

Lent, R.W., Brown, S.D., \& Hackett, G. (1994). Toward a unifying social cognitive theory of career and academic interest, choice, and performance. Journal of Vocational Behavior, 45(1), 79-122.

Lent, R.W., Brown, S.D., \& Hackett, G. (2000). Contextual supports and barriers to career choice: A social cognitive analysis. Journal of Counseling Psychology, 47(1), 36.

Lent, R.W., Brown, S.D., \& Hackett, G. (2002). Social cognitive career theory in Brown, D \& Associates (Eds). (2002). Career Choice and Development (4th Edn). John Wiley \& Sons.

Liguori, E.W., Bendickson, J.S., \& McDowell, W.C. (2018). Revisiting entrepreneurial intentions: a social cognitive career theory approach. International Entrepreneurship and Management Journal, 14(1) (2018) 67-78. http://dx.doi.org/10.1007/s11365-017-0462-7

Liñán, F., \& Chen, Y.W. (2009). Development and cross-cultural application of a specific instrument to measure entrepreneurial intentions. Entrepreneurship Theory and Practice, 33(3), 593-617.

Luszczynska, A., Scholz, U., \& Schwarzer, R. (2005). The general self-efficacy scale: multicultural validation studies. The Journal of Psychology, 139(5), 439-457.

McGee, J.E., Peterson, M., Mueller, S.L., \& Sequeira, J.M. (2009). Entrepreneurial self-efficacy: refining the measure. Entrepreneurship Theory and Practice, 33(4), 965-988. 
Nabi, G., \& Holden, R. (2008) Graduate entrepreneurship: intentions, education and training. Education and Training, 50(7), 545-51.

Naktiyok, A., Karabey, C.N., \& Gulluce, A.C. (2010.) Entrepreneurial self-efficacy and entrepreneurial intention: the Turkish case. International Entrepreneurship and Management Journal, 6(4), 419-435.

Newman, A., Obschonka, M., Schwarz, S., Cohen, M., \& Nielsen, I. (2019). Entrepreneurial self-efficacy: A systematic review of the literature on its theoretical foundations, measurement, antecedents, and outcomes, and an agenda for future research. Journal of Vocational Behavior, 110, 403-419.

Odoardi, C., Galletta, M., Battistelli, A., \& Cangialosi, N. (2019). Effects of beliefs, motivation and entrepreneurial self-efficacy on entrepreneurial intentions: The moderating role of family support. Roczniki Psychologiczne/Annals of Psychology, 21(3), 185-205.

Pihie, Z.A.L., \& Bagheri, A. (2013). Self-efficacy and entrepreneurial intention: The mediation effect of self-regulation. Vocations and Learning, 6(3), 385-401.

Piperopoulos, P., \& Dimov, D. (2015). Burst bubbles or build steam? Entrepreneurship education, entrepreneurial self-efficacy, and entrepreneurial intentions. Journal of Small Business Management, 53(4), 970-985.

Pittaway, L., Rodriguez-Falcon, E., Aiyegbayo, O., \& King, A. (2011). The role of entrepreneurship clubs and societies in entrepreneurial learning. International Small Business Journal, 29(1), 37-57.

Kayed, R.N., \& Kabir Hassan, M. (2011). Saudi Arabia's economic development: entrepreneurship as a strategy. International Journal of Islamic and Middle Eastern Finance and Management, 4(1), 52-73.

Ren, Z.Y., Ping, L.I., \& Li, Y.X. (2018, August). The Relationship between Entrepreneurial Self-Efficacy and Entrepreneurial Intention. In 2018 International Conference on Management Science and Engineering (ICMSE), IEEE, 517-522.

Saberi, M., \& Hamdan, A. (2019). The moderating role of governmental support in the relationship between entrepreneurship and economic growth. Journal of Entrepreneurship in Emerging Economies, 11(2), 200-216. http://dx.doi.org/10.1108/JEEE-10-2017-0072

Segal, G., Borgia, D., \& Schoenfeld, J. (2002). Using social cognitive career theory to predict selfemployment goals. New England Journal of Entrepreneurship, 5(2), 47-56.

Sequeira, J., Mueller, S.L., \& McGee, J.E. (2007). The influence of social ties and self-efficacy in forming entrepreneurial intentions and motivating nascent behavior. Journal of Developmental Entrepreneurship, 12(03), 275-293.

Sušanj, Z., Jakopec, A., \& Miljković Krečar, I. (2015). Verifying the model of predicting entrepreneurial intention among students of business and non-business orientation. Management: Journal of Contemporary Management Issues, 20(2), 49-69.

Thurik, R., \& Wennekers, S. (2004). Entrepreneurship, small business and economic growth. Journal of Small Business and Enterprise Development, 11(1), 140-149.

Van Gelderen, M., Brand, M., van Praag, M., Bodewes, W., Poutsma, E., \& Van Gils, A. (2008). Explaining entrepreneurial intentions by means of the theory of planned behaviour. Career Development International, 13(6), 538-559.

Wilson, F., Kickul, J., \& Marlino, D. (2007). Gender, Entrepreneurial Self-Efficacy, and Entrepreneurial Career Intentions: Implications for Entrepreneurship Education. Entrepreneurship Theory and Practice, 31(3), 387-406.

Wood, R., \& Bandura, A. (1989). Social cognitive theory of organizational management. Academy of Management Review, 14(3), 361-384.

Wu, S., Matthews, L., \& Dagher, G.K. (2007). Need for achievement, business goals, and entrepreneurial persistence. Management Research News, 30(12), 928-941. 
Wu, L., \& Li, J. (2011). Perceived value of entrepreneurship: A study of the cognitive process of entrepreneurial career decision. Journal of Chinese Entrepreneurship, 3(2), 134-146.

Zhang, P., Wang, D.D., \& Owen, C.L. (2015). A study of entrepreneurial intention of university students. Entrepreneurship Research Journal, 5(1), 61-82.

Zhao, H., Seibert, S.E., \& Hills, G.E. (2005). The mediating role of self-efficacy in the developpment of entrepreneurial intentions. Journal of Applied Psychology, 90(6), 1265. http://dx.doi.org/10.1037/0021-9010.90.6.1265

\section{Author}

\section{Pappusamy Udayanan}

Assistant Professor, Faculty of Business Management, Majan University College, Muscat, Oman. His research interests include the intentions of individuals in the areas of entrepreneurship, consumer behaviour, and human resources management.

Correspondence to: Dr. Pappusamy Udayanan, Assistant professor, Majan University College, Ruwi, PC 112, Oman, e-mail: pappusamy.udhaynan@majancollege.edu.om ORCID (1) http://orcid.org/0000-0002-8414-9536

\section{Copyright and License}

(9) (1) 9

This article is published under the terms of the Creative Commons Attribution - NoDerivs (CC BY-ND 4.0) License http://creativecommons.org/licenses/by-nd/4.0/

Published by the Centre for Strategic and International Entrepreneurship - Krakow, Poland 